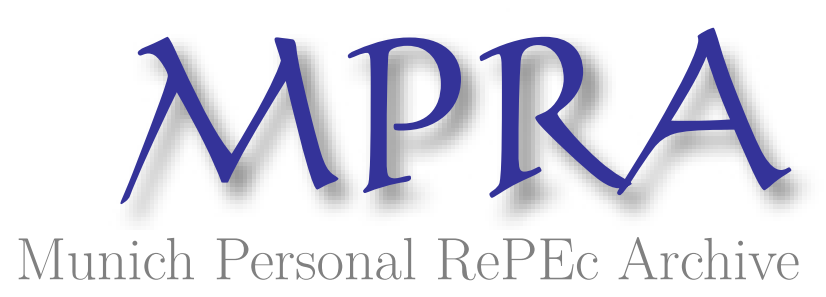

\title{
Student Study Choices in the Principles of Economics: A Case Study of Computer Usage
}

Grimes, Paul W. and Sanderson, Patricia L. and Ching, Geok H.

Mississippi State University, Mississippi State University, Mississippi State University

July 1996

Online at https://mpra.ub.uni-muenchen.de/63265/

MPRA Paper No. 63265, posted 29 Mar 2015 06:17 UTC 


\title{
STUDENT STUDY CHOICES IN THE PRINCIPLES OF ECONOMICS:
}

A CASE STUDY OF COMPUTER USAGE

\author{
ABSTRACT
}

Principles of Economics students at Mississippi State University were provided the opportunity to use computer assisted instruction (CAI) as a supplemental study activity. Students were free to choose the extent of their computer work. Throughout the course, weekly surveys were conducted to monitor the time each student spent with their textbook, computerized tutorials, workbook, class notes, and study groups. The surveys indicated that only a minority of the students actively pursued CAI. Probit and OLS models were estimated to identify the factors which determined the probability of computer use and the mean weekly time spent in CAI. The results indicated that black students spent significantly less time engaged in CAI but older students spent more time with the computer. Students with greater physical access to computers and students who had taken a formal course in computer operations spent more time each week in CAl. Further, students who highly rated the importance of CAl to their learning were more likely to be computer users and spend more time on task. The impact of CAI on student performance was estimated within the context of a "treatment effects" model which controlled for the self-selection of students into two categories of computer users. The results indicated that CAI did significantly improve end-of-course test performance, holding all else constant. Given the negligible use of CAl, the authors conclude that students failed to perceive the expected return to computer time or were willing to bear the opportunity cost of pursuing other study activities. 
Note: This is the final draft of the following article subsequently published as: "Student Study Choices in the Principles of Economics: A Case Study of Computer Usage." Journal of Educational Computing Research, Vol. 16, No. 1, 1997, pp. 65-81.

STUDENT STUDY CHOICES IN THE PRINCIPLES OF ECONOMICS:

A CASE STUDY OF COMPUTER USAGE

Paul W. Grimes

Professor of Economics

Patricia L. Sanderson

Associate Professor of Economics

Geok H. Ching

Doctoral Assistant in Economics

\author{
All Authors: \\ College of Business and Industry \\ Mississippi State University \\ $326 \mathrm{McCool} \mathrm{Hall} \mathrm{-} \mathrm{Box} 9580$ \\ Mississippi State, MS 39762-9580
}

July 1996

Draft - Not for Quotation

An earlier version of this paper was presented at the annual meetings of the Allied Social Sciences Association. The authors extend their appreciation to Keith Smith and Steve Canfield of the MSU COBI Computer Services Center and the Principles of Economics students who participated in this study. Valuable comments were provided by George Chressanthis and Charles Register. 


\section{STUDENT STUDY CHOICES IN THE PRINCIPLES OF ECONOMICS:}

\section{A CASE STUDY OF COMPUTER USAGE}

Today the microcomputer is a common feature in many college economics classrooms. The advent of powerful inexpensive hardware and the growing availability of computer assisted instruction (CAI) software tailored for specific textbooks and courses have made the microcomputer a popular teaching tool. Several recent studies have examined the effects of microcomputer usage on student outcomes in Principles of Economics courses. A review of this literature by Grimes and Ray [6] indicates that CAI is often found to increase student learning. The evidence to date suggests that computerized simulations may be more effective than computerized tutorials and that CAl in general is most effective for students at either end of the grade distribution. This latter conclusion is very important given that all previous studies have examined CAI when it is used in a formal classroom setting (e.g. a laboratory or as specific class assignments). Even though some departments have restructured their curriculum [1] or developed laboratory courses [10] which integrate CAI into the classroom, there is a growing trend for students to have access to CAl software in unstructured study environments. CAl software is often made available to students through local area networks or through diskettes bundled with textbooks. At many schools, instructors do not require CAl as part of their coursework but make it available to students as an optional study aid. In such situations, the extent of CAI is determined by the student who chooses to use the computer from a portfolio of study activities including more traditional learning aids such as workbooks and study groups. 
This case study first examines which students choose to use CAI materials when they are readily available as a learning aid but not a structured part of their course assignments. What characteristics influence a student's choice to utilize CAI relative to more traditional study activities? Are the students who are expected to benefit the most from CAI voluntarily using it? Secondly, this case study analyzes the effect of choosing CAI on student understanding of course material. Is time on the computer equivalent to time spent with a workbook or in a study group? Obviously, these issues are important to economic educators who must determine how the microcomputer should be used in the college classroom.

\section{THE SETTING AND ANALYSIS DESIGN}

This study was conducted at Mississippi State University (MSU). As a public Land Grant institution, MSU's student body is diverse representing all fifty states and several foreign nations. Total enrollment is approximately 14,000 . The average ACT score for first-year students is 22.5 . MSU offers the traditional Principles of Economics two-course sequence through the College of Business and Industry. All Principles of Economics students have access to a variety of textbook-based CAI programs through the College of Business and Industry Local Area Network (COBI-LAN). Most student use of the COBI-LAN occurs in standard multi-station laboratory settings or in an "electronic classroom" environment. The primary computer laboratory is available as a "walk-in" study area for extended hours each day of the semester. All software on the COBI-LAN operates under DOS or WINDOWS.

Two regular semester sections of the Principles of Macroeconomics (EC 2123) participated in this study. Both sections were taught by the same instructor who used the same textbook, course syllabus, and grading procedures in each class. Classroom lectures were held at similar times of day. At the beginning of the semester, each student was provided with a detailed handout describing the 
Principles of Economics CAI software available on the COBI-LAN. Students also received an extended set of instructions on how to use their textbook's CAI tutorial. ${ }^{1}$ However, students were not required to use the CAl software or to complete computer assignments. Use of the computer was left as an individual and voluntary decision.

Each week throughout the semester students were asked to complete a brief survey concerning their time spent studying and preparing for class. This survey was conducted in-class the same day of each week. Absent students were contacted and completed the survey by phone. All students were asked to indicate the number of hours during the previous week they spent engaged in five types of study activities for the course: ${ }^{2}$ 1) reading the textbook, 2) using the computerized tutorials, 3) using the workbook, 4) reviewing class notes, and 5) studying with someone else or in a group. Regular reading assignments from the textbook were made by the instructor throughout the semester but students were free to choose which additional study activities to pursue.

Demographic information about each student was collected at the beginning of the semester from questionnaires and official school records. In addition, all students were pre- and post-course tested with the Test of Understanding in College Economics, Third Edition (TUCE) [11]. Finally, at the end of the course students completed a questionnaire concerning their course experiences and attitudes toward the various study activities. (Copies of the course syllabus, study time survey, and questionnaires are available upon request from the authors.)

The data taken from the survey instruments reveal information about the characteristics of Principles of Economics students who chose to use CAI. Further, the TUCE data provide a means to measure the cognitive impact of CAI on students who self-select this form of study activity. Statistical analyzes of these data are outlined and discussed in the following sections. 


\section{STUDY TIME AND COMPUTER USAGE}

Data from the study time surveys were used to calculate the average number of hours per week each student spent engaged in the various study activities over the course of the semester. The averages were calculated for all students in the final sample and by degree of voluntary computer usage. $^{3}$ The upper portion of Table 1 reports the mean weekly hours, by study activity category, for all students in the sample, all Non-Users, all Users, and all "Heavy Users." A User is defined as any student who reported study time on the computer during at least one week of the semester. Heavy Users are the subset of all Users whose time on the computer exceeded the mean user time.

As indicated in Table 1, only 19.79 percent of the students in the sample took advantage of the CAI materials available to them. And only 6.25 percent could be classified as Heavy Users of the computer. Thus, students who voluntarily chose to use the computer represented a minority of the class. Time on the computer for all Users averaged only .12 hours ( 7 minutes) per week. Heavy Users averaged .28 hours (17 minutes) per week. ${ }^{4} \quad$ Work with the computer accounted for 4.78 percent of total study time for all Users and 8.97 percent of total study time for Heavy Users. The relatively slight incidence and degree of computer usage occurred even though students had been briefed on the benefits of CAl, provided with detailed instructions and easy access, and had agreed to participate in a research project which focused on study behavior. Apparently, voluntary CAI activity depends on more than just encouragement and opportunity.

- Insert Table 1 About Here

Table 1 suggests that computer users may employ CAI as a complement to other study activity and not as a substitute. Simple t-tests revealed no statistically significant difference between the 
weekly mean study times of computer Users and Non-Users for time with the textbook, workbook, class notes, or groups. Also, Heavy Users of the computer appear to have studied slightly more on average than Non-Users, in total. A t-test reveals that the mean total weekly study time for Heavy Users (3.11 hours) is significantly greater than that of Non-Users ( 2.19 hours) at the .10 level of confidence ( $\mathrm{t}$-value $=$ 1.69). Thus, serious users of the computer apparently studied for longer periods of time each week than those who chose not to utilize CAI.

It is clear that the textbook was the preferred study activity for each group. Textbooks are the traditional medium for delivery of detailed and sophisticated information. Given that students in the sample were asked each week to read selections from their text, it is not surprising that the mean time spent with the textbook was significantly greater than time spent in other forms of study pursuits for all

groups. When asked to evaluate the importance of each study activity, each group of students gave "Reading the Textbook" the highest rating. Class notes were also highly valued by each student group. The relative ratings for the study activities are reported in the lower portion of Table 1.

The computer received the lowest importance rating from all the student groups, including the Heavy Users of CAl. Not surprisingly, however, Users and Heavy Users did rate the computerized tutorials higher than the Non-Users. The low importance ratings and the relatively negligible overall utilization of the computer suggests that CAI was not a popular study activity for the average student in the sample. To identify what factors determine voluntary computer usage additional analysis of the data was performed.

\section{THE DETERMINANTS OF COMPUTER USAGE}

The voluntary use of CAI as a study activity in the Principles of Economics was assumed to be a function of a student's human capital attributes, personal characteristics, computer access and attitude 
toward computerized tutorials. These factors were viewed as the major determinants of an individual student's demand for computerized instruction. Using data collected from the instruments described above, four specifications of the following regression model were estimated:

CAI $=\alpha+\beta_{1}$ PRE TUCE $+\beta_{2}$ PRIOR ECONOMICS $+\beta_{3}$ ACT $+\beta_{4}$ GPA $+\beta_{5}$ STUDY $+\beta_{6}$ GENDER $+\beta_{7}$ BLACK +

$\beta_{8} A G E+\beta_{9}$ MAJOR $+\beta_{10}$ PRIOR COMPUTER $+\beta_{11}$ ACCESS $+\beta_{12}$ IMPORTANCE $+\varepsilon$

OLS and tobit estimations of the equation were calculated using the mean weekly hours of computer study time as the dependent CAI variable (COMPUTER TIME). The tobit specification was estimated to control for the natural truncation of the sample due to the significant number of students reporting zero hours. Two probit estimations were also calculated with dependent categorical variables identifying USERS and HEAVY USERS. The operational definition of each variable is reported in Table 2. Table 3 reports the mean and standard deviation of each variable for the total sample and by computer usage groups. Insert Tables 2 and 3 About Here

PRE TUCE and PRIOR ECONOMICS enter the model to control for a student's specific economics human capital. Students with lower levels of economics understanding and experience studying economics were expected to pursue study activities, such as CAI, to remediate their relative disadvantage. Likewise, ACT, GPA, and STUDY were included to control for more general aspects of student aptitude and academic effort. GENDER, BLACK, and AGE were used to capture any systematic differences across demographic groups in the propensity to choose CAl study activities. Because the CAI materials were accessed through the COBI-LAN facilities, MAJOR was included to control for 
differences in the familiarity and ease of laboratory access between business and non-business students. Students with greater degrees of computer experience and access were expected to be more receptive to the computerized tutorials. Thus, PRIOR COMPUTER and ACCESS were expected to enter the equation with positive signs. Likewise, IMPORTANCE was expected to positively affect CAl as students with more favorable attitudes towards computerized instruction were expected to take advantage of the computerized study aids. Insert Table 4 About Here

The estimated results for each specification of equation (1) are reported in Table 4. It is important to note that the OLS and tobit specifications estimate the independent variables' effects on COMPUTER TIME, while the probit equations examine the variables' effects on the probability that a student chose to be a USER or HEAVY USER of CAI. Thus, direct comparisons of the coefficients between the specifications cannot be made. One-tailed tests of statistical significance were conducted for those variables with a priori expected signs. Two-tailed tests were employed for coefficients with ambiguous expected signs. In addition to passing various specification tests, each estimated equation obtained acceptable diagnostic statistics as reported at the bottom of Table 4.

None of the human capital attribute variables were found to be significant in the OLS equation. However, two demographic characteristics were found to be important. BLACK students were found to spend less time with CAI relative to their white cohorts. Evaluation of the BLACK coefficient indicates that minority students spend about 38 percent less time per week with the computer than the sample mean. Given the positive and significant AGE coefficient, older students were found to choose more time per week with the computer. As expected, PRIOR COMPUTER experience and ACCESS were found to significantly increase the mean hours per week spent with the computerized tutorials. ${ }^{5}$ 
Finally, with respect to the OLS estimation, students who more highly rated the IMPORTANCE of computerized study activities were found to spend more hours per week pursuing CAl. (Recall from Table 2 that the IMPORTANCE scale runs from High $=1$ to Low $=5$. Thus, the negative coefficient indicates that students who more highly valued CAI spent more time on task.)

The COMPUTER TIME regression estimated by tobit yielded results similar and consistent with the OLS estimation. Again, black students were found to spend significantly less time with the computer while older students were found to allocate more study time to CAI. Likewise, the tobit results indicate that PRIOR COMPUTER experience and positive attitudes for CAI, as measured by the IMPORTANCE variable, significantly and positively affect COMPUTER TIME. In addition to collaborating the OLS results for these variables, the tobit estimation also found PRIOR ECONOMICS and ACT to be significant determinants of COMPUTER TIME. The negative PRIOR ECONOMICS coefficient indicates that students who had a previous course in economics spent less time using CAl. The negative ACT coefficient indicates that students with greater academic endowments also spent less time pursuing CAI. Together, these two coefficients imply that students with a stronger stock of human capital allocated less study time to CAl, relative to students with a weaker stock of human capital. Thus, the computerized tutorials may be seen as a remediation tool by students who require additional study assistance.

The results for the probit specifications were similar to the OLS and tobit results with respect to the AGE and IMPORTANCE variables. A student's age was found to significantly increase the probability that the student became a Heavy User of CAI and students who reported a more positive attitude toward the computerized tutorials were more likely to be Users or Heavy Users of the computer. Thus, older students and those with more positive computer attitudes were more likely to use the computer and to spend more time studying with it. 
Two human capital attributes, PRIOR ECONOMICS and ACT, were found to be significant factors in one or both of the probit specifications. Both were found to negatively effect the probability that a student would use the computer. Students who had not previously studied economics may have chosen CAI in order to "catch up" with their classmates who had taken a prior course in high school or college. $^{6}$ Again, the negative ACT coefficient may indicate that students with lower levels of overall academic aptitude seek out additional study aids, such as CAl, to remediate their academic position. Such students would have more to gain from successful CAI, holding all else constant, than students with relatively greater degrees of academic aptitude.

PRE TUCE, GPA, STUDY, GENDER and MAJOR were not found to be significant in any specification of the model. These factors apparently did not have significant independent effects on a student's decision to use the computer or the mean time spent with the course's CAI materials. Of the statistically significant variables, only IMPORTANCE was found to be significant across all four specifications of equation (1). Thus, student attitude toward computerized study is of primary importance in determining the extent of CAI use. Students who felt that CAl could not improve their course learning, relative to other modes of study, chose to use the computer to a significantly lesser extent than those students who perceived a learning benefit. This conclusion raises the question of whether CAI did or did not improve student understanding of course material. The next section addresses this important issue.

\section{COMPUTER USAGE AND ECONOMIC UNDERSTANDING}

Many of the empirical models of student learning in the economic education literature implicitly assume that the effects of study time are captured in other measures of student aptitude and effort

(e.g. grades and test scores). However, some researchers have developed formal models of student 
utility maximization to explain study time (e.g. [7] and [2]). Empirical tests of such models have not always verified the theoretically identified returns to total time spent studying [4]. Schmidt [12] found that components of total study time became significant within the traditional production function framework when time was disaggregated by type of study activity. Thus, students may be viewed as maximizers who choose between alternative study strategies within the portfolio of activities available to them. It is this perspective that is taken here.

As noted earlier, all previous studies examining the effects of CAI on student performance in the Principles course were conducted under quasi-experimental conditions. In these studies, one group of students would be given computer assignments (the treatment group) and another group would not (the control group). Researchers then tested for differences in performance between the two groups. In our case, students made the decision about who used the computer, not the instructor. Thus, in order to determine the effect of CAI on student performance we must first account for the probability of CAl being chosen as a study activity. This is a classic case of self-selection. Students self-selected themselves into the Users and Heavy Users groups.

The probit equations reported in Table 4 were used to calculate Heckman's selection estimators (the inverse of Mill's Ratio) for Users and Heavy Users. These were then used to estimate a "treatment effects" selection variant of the traditional education production function regression for the two groups. The treatment effects model utilizes the full sample (all 96 observations) to calculate the regression coefficients and has been previously applied in the returns to education literature. ${ }^{7}$ Thus, the following equation was estimated separately for Users and Heavy Users: 
POST TUCE $=\alpha+\delta_{1}$ PRE TUCE $+\delta_{2}$ PRIOR ECONOMICS $+\delta_{3}$ ACT $+\delta_{4}$ GPA $+\delta_{5}$ GENDER $+\delta_{6}$ BLACK $+\delta_{7}$ AGE + $\delta_{8}$ MAJOR $+\delta_{9}$ COMPUTER TIME $+\delta_{10}$ TEXTBOOK TIME $+\delta_{11}$ WORKBOOK TIME $+\delta_{12}$ NOTES TIME + $\delta_{13}$ GROUP TIME + LAMBDA $+\varepsilon$

Equation (2) is a slight modification of the standard production function prevalent in the empirical economics education literature [3]. As specified, a student's study time explicitly enters the model in a disaggregated form through the five study activity variables. Lambda is the selection term which controls for the probability that a student chose the treatment (computer usage) which defines the relevant sample. The estimated results are reported in Table 5.

Insert Table 5 About Here

Table 5 reveals that the results are similar across the Users and Heavy Users samples. Both estimated equations obtained significant F-statistics and acceptable $R^{2}$ values. Lambda, the selection term, was not found to be statistically significant in either equation. Even though Lambda was found to be insignificant, the design of this study required us to account for the voluntary selection of treatment by the student subjects.

Although neither estimation yielded statistically significant coefficients for the demographic variables, PRE TUCE, ACT, and GPA were found to be significant positive determinants of end-of-course economic understanding for both samples. These findings are consistent with a priori expectations and the established empirical literature.

Only one study activity variable was found to have a statistically significant effect on student performance. COMPUTER TIME entered the Users equation with a positive coefficient significant at 
the .05 level (two-tailed test). Evaluation of this coefficient suggests that a one hour increase in the average weekly time spent with CAI would improve POST TUCE performance by almost 9 points, ceteris paribus. This is a substantial return given the distribution of PRE TUCE and POST TUCE scores (see Table 3). ${ }^{8} \quad$ However, it must be recalled that students in the samples averaged far less than one hour a week engaging in CAl opportunities. This suggests that students failed to perceive the predicted return to CAl or were willing to bear the opportunity cost of choosing alternative study activities. The insignificance of the other study time coefficients suggest a stronger test performance return to CAI relative to more traditional study activities, holding all else constant.

\section{CONCLUSIONS}

Several conclusions can be drawn from the case study presented here. First, the computer was not found to be a popular elective study tool with students in a typical Principles of Economics course. Even when students were provided easy access, a relative minority voluntarily chose CAI as a study activity. Those who did pursue CAI spent only a minimal amount of their total class study time with the

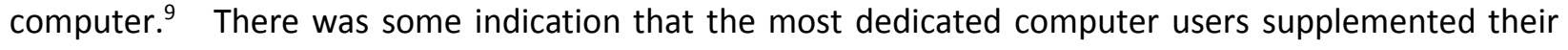
study time with the computer rather than to substitute computer time for time spent in other study activities.

Second, our model of computer usage indicated that two demographic characteristics significantly influenced computer use. Black students were found to use the computer significantly

less than their white cohorts. Age was found to be positively related to averaging more study hours on the computer each week. Such findings suggest that additional attention should be placed on these two characteristics of students when computerized instruction is incorporated into course design. 
The third major conclusion drawn from our results involves the ease of access and student computer endowments and attitude. Students with greater physical access to computers and students who had taken a formal course in computer operations spent more time each week with CAI. Most significantly, students who highly rated the importance of CAI to their learning were more likely to be computer users and spend more time on task. Students must be convinced that CAI will generate a performance reward before they will undertake this activity which is not part of their normal study routine. Casual empiricism supports this conclusion. Conversations with students in the sample indicated than many did not pursue the computerized tutorials because they felt the computer quizzes and problems were not relevant to the material they were seeing in class and on exams. Software authors and instructors need to insure that the relevance of material is clear to all students who choose to pursue CAI.

The fourth and final major conclusion concerns the effect of CAI on student performance. Results from a treatment effects selection model indicated that computer time for students who voluntarily chose CAl activities significantly improved post-course test performance, ceteris paribus. Time spent in more traditional study activities was not found to improve student performance. Given the negligible use of CAI, we must conclude that students failed to perceive the expected return to time on the computer or were willing to bear the opportunity cost by pursuing other study activities.

This case study illustrates that economic educators need to assess the behavior of students when introducing new pedagogical tools in their classrooms. Additional research is needed to explore how courses can be designed to encourage the use of beneficial instructional technologies. Our results suggest that when given the freedom of choice, students may not necessarily perceive which activities provide the greatest return. 


\section{REFERENCES}

1. Bartlett R. and King P., Teaching economics as a laboratory science. Journal of Economic Education 21, 181-194 (1990).

2. Becker W. E., Economic education research: Part II, new directions in theoretical model building. Journal of Economic Education 14 4-10 (1983).

3. Becker W. E. and Walstad W. B., Econometric modeling in economic education research. Kluwer-Nijhoff Publishing, Boston (1987).

4. Gleason J. P. and Walstad W. B., An empirical test of an inventory model of student study time. Journal of Economic Education 19 315-321 (1988).

5. Greene W. H., Limdep version 6.0 - Users manual and reference guide. Econometric Software Incorporated, Bellport NY (1992).

6. Grimes P. W. and Ray M. A., Economics: Microcomputers in the college classroom - A review of the academic literature. Social Science Computer Review 11 452-463 (1993).

7. Kelley A. C., The student as utility maximizer. Journal of Economic Education 7 82-92 (1975).

8. Maxwell N. L. and Lopus J. S., The Lake Wobegon Effect in Student Self-Reported Data. American Economic Review 84 201-205 (1994).

9. Parkin M., Economics - Second Edition. Addison-Wesley Publishing Company, New York (1993).

10. Ray M. A., Economics 2131: Computer laboratory in economics - a supplement to principles of economics. In Economic Education Experiences of Enterprising Teachers 141-148. Joint Council on Economic Education, New York (1991).

11. Saunders P., Test of understanding in college economics - Examiner's manual. Joint Council on Economic Education, New York (1991).

12. Schmidt R. M., Who maximizes what? A study in student time allocation. American Economic Review 73 23-27 (1983). 
${ }^{1}$ The textbook for the course was Michael Parkin's Economics [9]. A CAl package entitled Economics in Action is distributed with this textbook. Economics in Action is a state of the art tutorial, quiz, graphing, demonstration and testing program that covers the main themes of a Principles of Economics course. The instructional material utilizes a Windows-like graphical user interface. The user navigates the program with either a mouse or keyboard using a series of menus and icons. All students in the course were provided with a ten page handout describing the program and the various units of material that it covers. In addition, any student who requested help getting started with the program was given assistance by the graduate teaching assistant or the instructor. Further, information and handouts concerning the availability of CAI programs being used in other sections were also provided.

${ }^{2}$ Maxwell and Lopus [8] report that students may inflate their academic achievements when data is collected by survey. The frequency of our surveys and the personal nature of the data collection process minimizes this problem.

${ }^{3}$ The original sample contained 104 students. Eight students failed to complete the course due to schedule change, university withdrawl, or personal illness. All statistical calculations are based on the final sample of 96 students. Analysis of the data did not indicate a statistically significant self-selection problem for the investigative sample. Only one student who failed to complete the course was a computer user. The complete database constructed for this study is available upon request from the authors.

${ }^{4}$ Examination of the study time surveys indicate that approximately one half of the computer users worked with the CAl material only one or two times. Further, the surveys report that a majority of computer time occurred in the early and middle part of the semester. Thus, some degree of "sampling" appears to have taken place and some students did not find the experience beneficial for them. Also, as expected, computer time demonstrated a pattern of "batch" use occurring immediately prior to scheduled examinations.

${ }^{5}$ Examination of the data revealed that black students may have had a lower incidence of prior computer experience than white students. An alternative specification of Equation (1) which included an interaction term between BLACK and PRIOR COMPUTER was estimated by OLS. The results indicated completion of a computer course significantly reduces the estimated BLACK effect on CAl study time. Complete copies of these results are available upon request.

${ }^{6}$ Most students who reported completing a prior course in economics had done so at the high school level. At MSU, Principles of Macroeconomics (EC 2113) is the first course of the Principles sequence. However, because of transfer students from other schools and because some students fail to take the sequence in the recommended order, EC 2113 is not everyone's first college economics course at MSU. 
${ }^{7}$ The treatment effects form of the selection model allows the equation to be estimated with a sufficient number of degrees of freedom. The entire sample of 96 observations is used in the estimation. See Greene [5] for a discussion of this technique.

${ }^{8}$ It is reasonable to assume that study time is subject to diminishing marginal returns. To account for this, the following logarithmic specification of Equation (2) was estimated for both Users and Heavy Users:

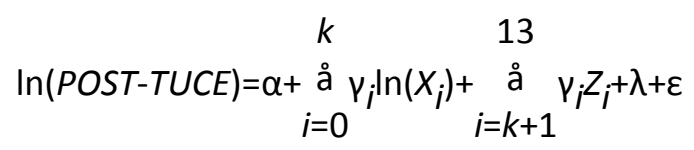

where $X$ represents the study time inputs and $Z$ represents the other determinants of student understanding. The results are consistent with the linear form of the model presented in Table 5. The In(COMPUTER TIME) was found to be positive and significant for Users $(0.428$ with a $t=2.114)$, but marginally insignificant for Heavy Users $(0.034$ with a $t=1.256)$. The other study time variables were insignificant. Copies of the complete logarithmic estimations are available upon request from the authors.

${ }^{9}$ The relatively low levels of computer use may be a reflection of the current state of educational software sophistication and not of CAI as a study activity. Future advancements in CAl technology which enhance learning efficiency may encourage greater levels of use. 
Table 1

STUDY ATTITUDES AND BEHAVIOR BY COMPUTER USAGE:

MEANS AND STANDARD DEVIATIONS OF SURVEY RESPONSES

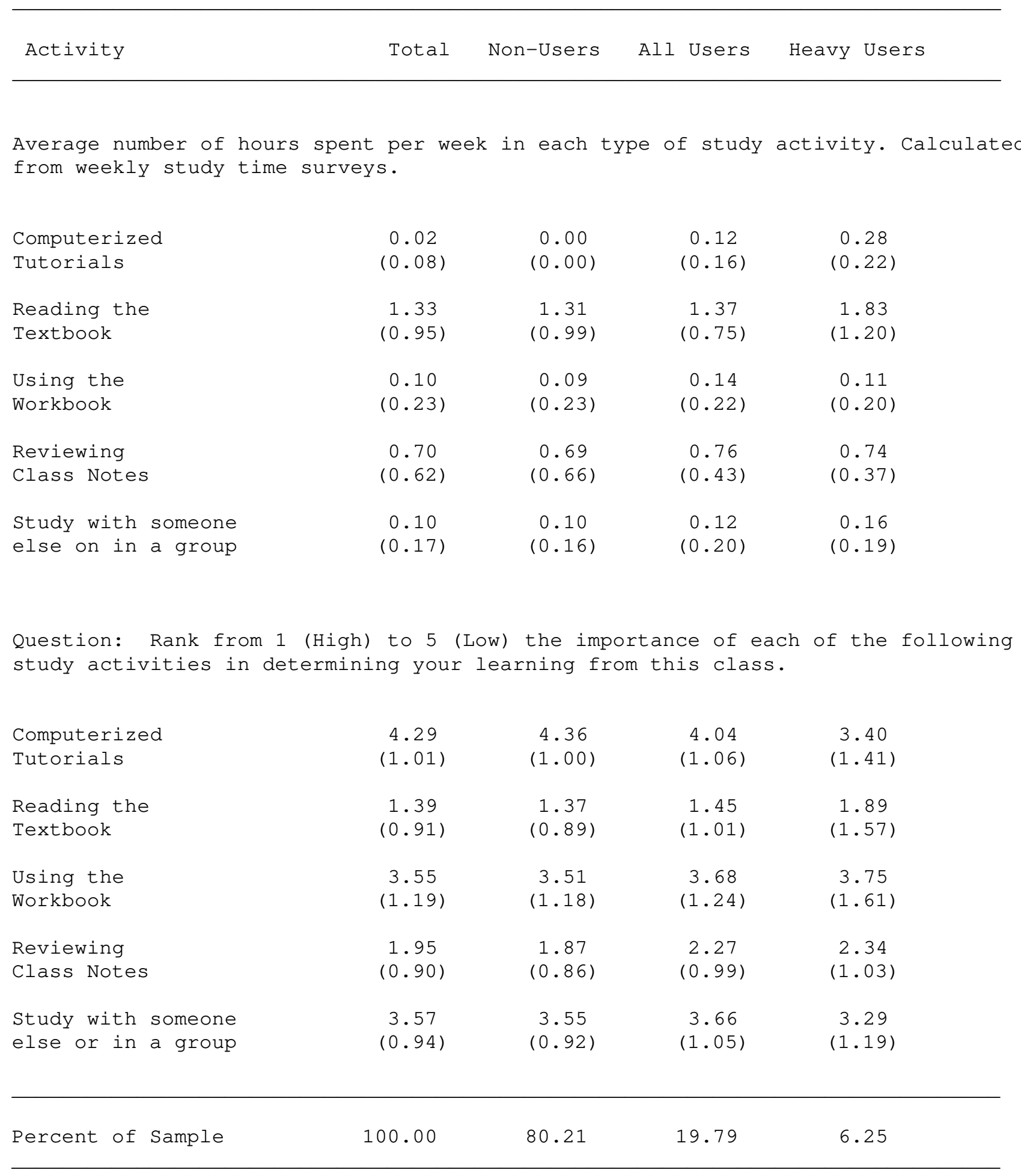


Table 2

SPECIFICATION OF VARIABLES

\begin{tabular}{|c|c|}
\hline Variable & Definition \\
\hline COMPUTER TIME & $\begin{array}{l}\text { Average number of hours per week studying } \\
\text { with computerized tutorials }\end{array}$ \\
\hline USER & $\begin{array}{l}\text { Student used computerized tutorials during } \\
\text { the semester at least once }=1 \text {; otherwise }=0\end{array}$ \\
\hline HEAVY USER & $\begin{array}{l}\text { Study time with computerized tutorials is } \\
\text { greater than the User mean }=1 ; \text { otherwise }=0\end{array}$ \\
\hline POST TUCE & $\begin{array}{l}\text { Test of Understanding College Economics score at } \\
\text { conclusion of course }\end{array}$ \\
\hline PRE TUCE & $\begin{array}{l}\text { Test of Understanding College Economics score prior } \\
\text { to start of course }\end{array}$ \\
\hline PRIOR ECONOMICS & $\begin{array}{l}\text { Student had completed previous course in economics } \\
\text { (college or high school) }\end{array}$ \\
\hline $\mathrm{ACT}$ & Score on the American College Test \\
\hline GPA & Cumulative grade point average (4 point scale) \\
\hline STUDY & $\begin{array}{l}\text { Average number of study hours per week for course } \\
\text { (non-computer hours) }\end{array}$ \\
\hline GENDER & Female $=1 ;$ Male $=0$ \\
\hline BLACK & Black $=1 ;$ White or other $=0$ \\
\hline AGE & Age in years \\
\hline MAJOR & Business major $=1$; otherwise $=0$ \\
\hline PRIOR COMPUTER & $\begin{array}{l}\text { Student had completed previous course in computer use } \\
\text { (college or high school) }\end{array}$ \\
\hline ACCESS & $\begin{array}{l}\text { Computer available to student at place of residence } \\
\text { or work }=1 \text {; otherwise }=0\end{array}$ \\
\hline IMPORTANCE & $\begin{array}{l}\text { Importance of computerized tutorials to learning; } \\
\text { categorical variable running } 1 \text { (High) to } 5 \text { (Low) }\end{array}$ \\
\hline TEXTBOOK TIME & Average study hours per week reading the textbook \\
\hline WORKBOOK TIME & Average study hours per week using the workbook \\
\hline NOTES TIME & Average study hours per week reviewing class notes \\
\hline GROUP TIME & $\begin{array}{l}\text { Average hours per week studying with someone else } \\
\text { or in a group }\end{array}$ \\
\hline
\end{tabular}


Table 3

MEANS AND STANDARD DEVIATIONS OF REGRESSION VARIABLES

\begin{tabular}{|c|c|c|c|c|}
\hline Variable & Total & Non-Users & All Users & Heavy Users \\
\hline COMPUTER TIME & $\begin{array}{c}0.02 \\
(0.08)\end{array}$ & $\begin{array}{c}0.00 \\
(0.00)\end{array}$ & $\begin{array}{c}0.12 \\
(0.16)\end{array}$ & $\begin{array}{c}0.28 \\
(0.22)\end{array}$ \\
\hline USER & $\begin{array}{c}0.20 \\
(0.40)\end{array}$ & $\begin{array}{c}0.00 \\
(0.00)\end{array}$ & $\begin{array}{l}1.00 \\
(0.00)\end{array}$ & $\begin{array}{c}1.00 \\
(0.00)\end{array}$ \\
\hline HEAVY USER & $\begin{array}{c}0.06 \\
(0.24)\end{array}$ & $\begin{array}{c}0.00 \\
(0.00)\end{array}$ & $\begin{array}{c}0.32 \\
(0.48)\end{array}$ & $\begin{array}{c}1.00 \\
(0.00)\end{array}$ \\
\hline POST TUCE & $\begin{array}{l}11.88 \\
(4.32)\end{array}$ & $\begin{array}{l}12.08 \\
(4.32)\end{array}$ & $\begin{array}{l}11.05 \\
(4.33)\end{array}$ & $\begin{array}{l}13.17 \\
(5.19)\end{array}$ \\
\hline PRE TUCE & $\begin{array}{c}9.08 \\
(2.68)\end{array}$ & $\begin{array}{c}9.30 \\
(2.76)\end{array}$ & $\begin{array}{c}8.21 \\
(2.15)\end{array}$ & $\begin{array}{c}8.67 \\
(2.66)\end{array}$ \\
\hline PRIOR ECONOMICS & $\begin{array}{c}0.59 \\
(0.49)\end{array}$ & $\begin{array}{c}0.64 \\
(0.48)\end{array}$ & $\begin{array}{c}0.42 \\
(0.51)\end{array}$ & $\begin{array}{c}0.17 \\
(0.41)\end{array}$ \\
\hline $\mathrm{ACT}$ & $\begin{array}{l}21.70 \\
(4.51)\end{array}$ & $\begin{array}{l}22.25 \\
(4.57)\end{array}$ & $\begin{array}{l}19.50 \\
(3.58)\end{array}$ & $\begin{array}{l}20.40 \\
(4.71)\end{array}$ \\
\hline GPA & $\begin{array}{c}2.75 \\
(0.60)\end{array}$ & $\begin{array}{c}2.76 \\
(0.58)\end{array}$ & $\begin{array}{l}2.68 \\
(0.68)\end{array}$ & $\begin{array}{c}2.73 \\
(0.79)\end{array}$ \\
\hline STUDY & $\begin{array}{c}2.24 \\
(1.54)\end{array}$ & $\begin{array}{c}2.19 \\
(1.65)\end{array}$ & $\begin{array}{c}2.40 \\
(1.02)\end{array}$ & $\begin{array}{c}2.84 \\
(1.26)\end{array}$ \\
\hline GENDER & $\begin{array}{c}0.25 \\
(0.44)\end{array}$ & $\begin{array}{c}0.26 \\
(0.44)\end{array}$ & $\begin{array}{c}0.21 \\
(0.41)\end{array}$ & $\begin{array}{c}0.17 \\
(0.41)\end{array}$ \\
\hline BLACK & $\begin{array}{c}0.14 \\
(0.34)\end{array}$ & $\begin{array}{c}0.14 \\
(0.35)\end{array}$ & $\begin{array}{c}0.11 \\
(0.32)\end{array}$ & $\begin{array}{c}0.00 \\
(0.00)\end{array}$ \\
\hline AGE & $\begin{array}{l}21.05 \\
(4.21)\end{array}$ & $\begin{array}{l}20.86 \\
(3.99)\end{array}$ & $\begin{array}{l}21.84 \\
(5.06)\end{array}$ & $\begin{array}{l}24.50 \\
(7.99)\end{array}$ \\
\hline MAJOR & $\begin{array}{c}0.28 \\
(0.45)\end{array}$ & $\begin{array}{c}0.29 \\
(0.45)\end{array}$ & $\begin{array}{l}0.26 \\
(0.45)\end{array}$ & $\begin{array}{c}0.33 \\
(0.52)\end{array}$ \\
\hline PRIOR COMPUTER & $\begin{array}{c}0.88 \\
(0.33)\end{array}$ & $\begin{array}{c}0.87 \\
(0.34)\end{array}$ & $\begin{array}{c}0.89 \\
(0.32)\end{array}$ & $\begin{array}{c}0.83 \\
(0.41)\end{array}$ \\
\hline ACCESS & $\begin{array}{c}0.72 \\
(0.45)\end{array}$ & $\begin{array}{c}0.71 \\
(0.45)\end{array}$ & $\begin{array}{c}0.74 \\
(0.45)\end{array}$ & $\begin{array}{c}0.83 \\
(0.41)\end{array}$ \\
\hline IMPORTANCE & $\begin{array}{c}4.29 \\
(1.01)\end{array}$ & $\begin{array}{c}4.36 \\
(1.00)\end{array}$ & $\begin{array}{c}4.04 \\
(1.06)\end{array}$ & $\begin{array}{c}3.40 \\
(1.41)\end{array}$ \\
\hline $\mathrm{N}$ & 96 & 77 & 19 & 6 \\
\hline
\end{tabular}

Note: Descriptive statistics for TEXTBOOK TIME, WORKBOOK TIME, NOTES TIME, and GROUP TIME can be fOund in the upper portion of Table 1 . 
Table 4

THE DETERMINANTS OF COMPUTER USAGE: OLS AND PROBIT RESULTS

\begin{tabular}{|c|c|c|c|c|}
\hline \multirow[b]{2}{*}{ Variable } & OLS & Tobit & \multicolumn{2}{|c|}{ Probit } \\
\hline & COMPUTER TIME & COMPUTER TIME & USER & HEAVY USER \\
\hline CONSTANT & $\begin{array}{c}-0.121 \\
(1.411)\end{array}$ & $\begin{array}{l}-0.096 \\
(0.331)\end{array}$ & $\begin{array}{l}1.593 \\
(0.909)\end{array}$ & $\begin{array}{c}6.37 \\
(1.43)\end{array}$ \\
\hline PRE TUCE & $\begin{array}{l}-0.002 \\
(0.654)\end{array}$ & $\begin{array}{l}-0.001 \\
(0.799)\end{array}$ & $\begin{array}{l}-0.056 \\
(0.776)\end{array}$ & $\begin{array}{c}0.158 \\
(0.780)\end{array}$ \\
\hline PRIOR ECONOMICS & $\begin{array}{l}-0.006 \\
(0.365)\end{array}$ & $\begin{array}{c}-0.080+ \\
(1.284)\end{array}$ & $\begin{array}{c}-0.440+ \\
(1.296)\end{array}$ & $\begin{array}{c}-6.768++ \\
(1.613)\end{array}$ \\
\hline $\mathrm{ACT}$ & $\begin{array}{l}-0.002 \\
(0.922)\end{array}$ & $\begin{array}{c}-0.016^{\star} \\
(1.767)\end{array}$ & $\begin{array}{l}-0.109 * \star \\
(2.103)\end{array}$ & $\begin{array}{l}-0.033 \\
(0.379)\end{array}$ \\
\hline GPA & $\begin{array}{c}0.019 \\
(1.109)\end{array}$ & $\begin{array}{c}0.042 \\
(0.705)\end{array}$ & $\begin{array}{c}0.159 \\
(0.468)\end{array}$ & $\begin{array}{c}0.226 \\
(0.323)\end{array}$ \\
\hline STUDY & $\begin{array}{l}0.002 \\
(0.433)\end{array}$ & $\begin{array}{c}0.012 \\
(0.574)\end{array}$ & $\begin{array}{c}0.048 \\
(0.435)\end{array}$ & $\begin{array}{c}0.297 \\
(0.811)\end{array}$ \\
\hline GENDER & $\begin{array}{l}-0.016 \\
(0.839)\end{array}$ & $\begin{array}{l}-0.043 \\
(0.578)\end{array}$ & $\begin{array}{l}-0.202 \\
(0.485)\end{array}$ & $\begin{array}{c}0.673 \\
(0.701)\end{array}$ \\
\hline BLACK & $\begin{array}{c}-0.046 \star \\
(1.737)\end{array}$ & $\begin{array}{l}-0.130 * \\
(1.300)\end{array}$ & $\begin{array}{l}-0.516 \\
(0.945)\end{array}$ & $\begin{array}{r}-14.621 \\
(0.033)\end{array}$ \\
\hline$A G E$ & $\begin{array}{l}0.009 * \star \star \\
(4.776)\end{array}$ & $\begin{array}{l}0.019 * \star \star \\
(3.001)\end{array}$ & $\begin{array}{c}0.035 \\
(0.909)\end{array}$ & $\begin{array}{c}0.478 * \\
(1.930)\end{array}$ \\
\hline MAJOR & $\begin{array}{l}-0.005 \\
(0.253)\end{array}$ & $\begin{array}{l}-0.034 \\
(0.495)\end{array}$ & $\begin{array}{l}-0.194 \\
(0.510)\end{array}$ & $\begin{array}{c}0.237 \\
(0.222)\end{array}$ \\
\hline PRIOR COMPUTER & $\begin{array}{c}0.035+ \\
(1.452)\end{array}$ & $\begin{array}{c}0.080+ \\
(1.289)\end{array}$ & $\begin{array}{l}0.409 \\
(0.735)\end{array}$ & $\begin{array}{c}0.409 \\
(0.280)\end{array}$ \\
\hline ACCESS & $\begin{array}{c}0.023+ \\
(1.297)\end{array}$ & $\begin{array}{c}0.036 \\
(0.538)\end{array}$ & $\begin{array}{c}0.075 \\
(0.206)\end{array}$ & $\begin{array}{l}-0.688 \\
(0.680)\end{array}$ \\
\hline IMPORTANCE & $\begin{array}{l}-0.017 * \star \\
(2.074)\end{array}$ & $\begin{array}{l}-0.058 * \star \\
(1.995)\end{array}$ & $\begin{array}{c}-0.225+ \\
(1.334)\end{array}$ & $\begin{array}{l}-1.020++ \\
(1.697)\end{array}$ \\
\hline $\begin{array}{l}\text { F-Statistic } \\
\mathrm{R}^{2} \\
\text { Log-Likelihood } \\
\text { Chi-Squared } \\
\text { Pseudo } \mathrm{R}^{2}\end{array}$ & $\begin{array}{r}2.778 \\
.287\end{array}$ & -17.876 & $\begin{array}{r}14.768 \\
.823\end{array}$ & $\begin{array}{r}25.744 \\
.948\end{array}$ \\
\hline $\begin{aligned} \text { ( ) } & \text { - Absolute Value } \\
+ & \text { - Statistically } \\
++ & \text { - Statistically } \\
* & \text { - Statistically } \\
* * & \text { - Statistically } \\
* * * & \text { - Statistically }\end{aligned}$ & $\begin{array}{l}\text { of t-statistic. } \\
\text { significant at the } .10 \\
\text { significant at the } .05 \\
\text { significant at the } .10 \\
\text { significant at the } .05 \\
\text { significant at the } .01\end{array}$ & $\begin{array}{l}\text { level, one-tailed } \\
\text { level, one-tailed } \\
\text { level, two-tailed } \\
\text { level, two-tailed } \\
\text { level, two-tailed }\end{array}$ & $\begin{array}{l}\text { test. } \\
\text { test. } \\
\text { test. } \\
\text { test. } \\
\text { test. }\end{array}$ & \\
\hline
\end{tabular}


Table 5

THE DETERMINANTS OF ECONOMIC UNDERSTANDING: SELECTION MODEL RESULTS

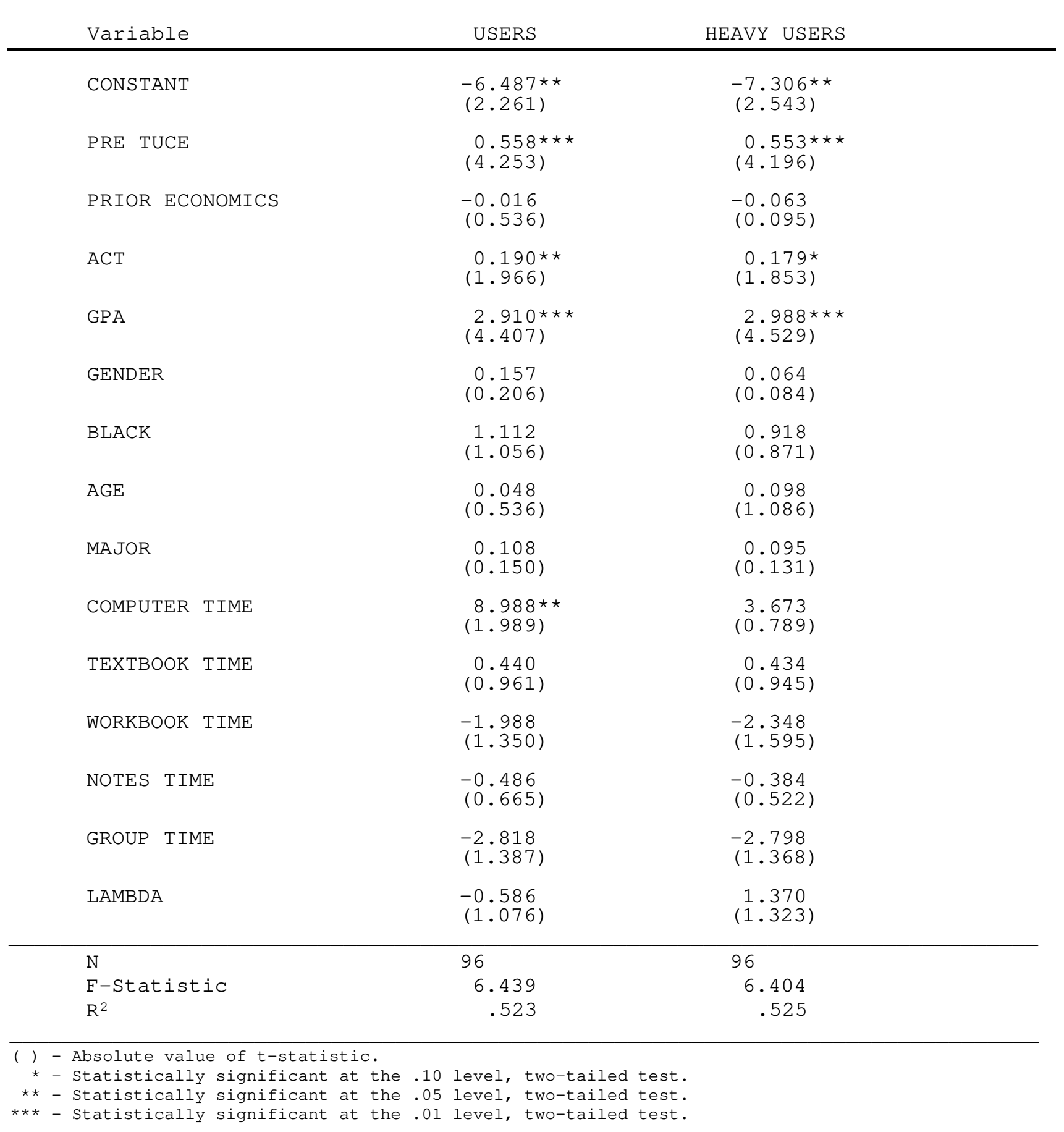

